\title{
Baculoviral IAP Repeat-Containing Protein
} 2

National Cancer Institute

\section{Source}

National Cancer Institute. Baculoviral IAP Repeat-Containing Protein 2. NCI Thesaurus.

Code C20931.

Baculoviral IAP repeat-containing protein $2(618 \mathrm{aa}, \sim 70 \mathrm{kDa})$ is encoded by the human BIRC2 gene. This protein plays a role in the regulation of apoptosis. 